\title{
COMPARATIVE STUDY OF AQUATIC FLORAS FOUND IN (SHIVNI AND CHORKHUND DAM) GHATANJI AREA DIST, YAVATMAL MAHARASTRA (INDIA)
}

\author{
C. R. Kasar \\ S. P. M. Science and Gilani Arts, Commerce College, Ghatanji \\ Dist. Yavatamal. 445301 (M.S.) India. \\ chandrashekharkasar8954@gmail.com
}

\begin{abstract}
:
Shivni Ta: Ghatanji, Dist., Yavatamal. (M.S.) India, Location 200-9'-30”, 780-25'-50" Area (sq.k.m.) 6.99. Utility value: Irrigation .Chorkhund, Ta: Ghatanji, Dist., Yavatamal. (M.S.) India, Location, 190-50'-00", 780-2'-30" Area (sq.k.m.) 8.24. Utility value: Irrigation .These two fresh water resources (dam) were selected for comparative study of aquatic floras found in Ghatanji area Dist. Yavatamal (M. S.)India. During the year 2018-2019. Total seventeen species of aquatic floras belonging to fourteen families were found, out of which Seven in Shivni, whereas eleven in Chorkhund, The comparative study shows the impacts on fresh water resources (Dam). Both the dams are seriously affected by unwanted growth of aquatic weeds. They were reducing the storage, conveyance capacity of dams and Impede recreational activities like swimming, fishing and boating. They may also cause physicochemical changes like reduction in oxygen levels and present gaseous exchange with water resulting in adverse fish production. They can provide a favorable and protected habitat for disease vectors mainly the insects. The rapid spread of aquatic weeds in the dam's vegetative and other means is creating serious socio-economic problems. Comparative study shows Chorkund dam were more affected by this problem as above than the Shivani Dam. So the management of weeds is important. So that, the action should be taken by the concerning department for to improving the availability of dam water which is mainly used for animal and irrigation purposes.
\end{abstract}

Key words: - Aquatic floras, comparative, impact, fresh water resources.

\section{INTRODUCTION:}

The village Shivni and Chorkhund are situated in Ghatanji taluka, Dist., Yavatamal. Shivni is located in between 200-9'-30", 780-25'-50" and the Dam has catchment area of 6.99(sq.k.m.). And Chorkhund dam is located in between (190-50'-00", 780-2'-30") and Area (sq.k.m.) 8.24 The maximum depth is 22 feet, and 32 feet respectively. Depth of water changes from season to season. The water is used mainly for irrigation and drinking purpose by the nearest villages. So that the scientific study on the reservoir were undertaken throughout the year (2018-2019) to find out the aquatic floras in both (Shivni and Chorkhund) Dam.

MATERIAL \& METHODS:
The fresh water bodies selected for the present investigation are situated on different locations i: e Shivni and Chorkhund. Both the dams are surrounded by open hills and the main source of water which drains during monsoon and also Small River, streams, nala and many seasonal sources. Aquatic floras in shallow water can be collected by hand while those from deeper waters with the help of long handed hook net. Collected specimens are thoroughly washed and excess water soaked with a filter paper, kept in polythene bag and brought to the laboratory. The aquatic floras were identify and classified with the help of literature.

RESULTS AND DISCUSSION: 
Total seventeen species of aquatic floras belonging to fourteen families were found, out of which Seven in Shivni, whereas eleven in Chorkhund, The comparative study shows the impacts on fresh water resources (Dam). Both the dams are seriously affected by unwanted growth of aquatic floras. In Shivni dam these aquatic flora are found viz Hydrillla verticillata,

(Hydrillla) Potamogeton diversifolius, (Pond weed). Polygonum amphibium L.(W.smart weed). Cladophora spp.(Cotton mat t. alga ). Typha spp.(Common cattail). Anabaena spp (Blue green alga) Spirogyra spp. (Slimy green alga) and in Chorkhund dam, Hydrilla verticillata, (Hydrillla).Potamogeton Crispus L.(Curly-leaf P. weed )., Ipomoea aquatic ,( Kalmi) Vallisneria spiralis .,(Eel weed)., Najas minor.,(Naiad ).,Cladophora spp.(Cotton matt. alga) Anabaena spp.(Blue green alga) Spirogyra spp.( Slimy green alga) these aquatic flora are found .During the observation and comparative study, It has been found that in both the dam the species belong to family Hydrocharitaceae., Cladophoraceae., Nostocaceae ., Chlorophyceae ., are same. But difference in Chorkhund dam the other species are also found belong to other families viz. Convolvulaceae. Najadaceae. And types of aquatic flora and Number of times are found in the dams are also different. The individual impacts of aquatic floras on water body are follows: Hydrilla verticillata- Alone dominated the other plants. They restrict the movement of organisms mainly the fishes and provide shelter to small size predatory fishes and insects. Potamogeton diversifoliusserve competition exits with planktonic algae for nutrients and results in decreased production and disturbs water quality. Polygonum amphibium L.- It had been observed in and around water-bodies. The ecological environment of this region is highly congenial for growth, reproduction and dissemination of this weed. Cladophora spp.The filamentous alga produces undesirable odors and also spoils the taste of drinking water. Typha spp.- Plants are found along the shoreline of water body. They provide shelter to small size predatory fishes and insects. Anabaena spp.- Excessive phytoplankton booms may result to zooplankton developments which may deplete water and lead to eutrophication which may prove destructive to fish and other aquatic life. The impacts were noticed that dams are seriously affected by unwanted growth of aquatic floras. The rapid spread of aquatic floras in the dam's vegetative and other means is creating serious socio-economic problems. Depending on the species and abundance of these weeds it is often necessary to control them

\section{CONCLUSIONS}

Comparative study shows Chorkund Dam were more affected by aquatic floras than the Shivni Dam. So the management of weeds is important. So that, the action should be taken by the concerning department for to improving the availability of dam water which is mainly used for animal and irrigation purposes.

\section{ACKNOWLEDGEMENT :}

The authors are thankful to the Principal Dr. M. A. Shahezad, S. P. M. science \& Gilani Arts, Comm., college, Ghatanji for providing the research laboratory facilities to carry out this work. They also thankful to the H. O. D. Dr. A. K. Patki.

\section{REFERENCES:}

Kumar M. and J. Singh., Environmental impacts of aquatic weeds and their Classification. Proc. the works, on management of aquatic weed, Amritsar, Punjab, India (1987) 
Mandal R.C., Weed, weedicide and weed control, Agrobios, Jodhpur, 128-154(2007)

Cook C.D.K., Aquatic and Wetland Plants of India, Oxford University Press. Delhi, 22-370 (1996)

Joshi P.P. Study on Diversity, Taxonomy and Impact of Macrophytes on the Fresh Water Resources (Minor Project-Dam) of Yavatamal District, Maharashtra, India. IRJES Vol. 1(5), 1-5, December (2012) .

Murphy K.J., Aquatic weed problems and their management, a review, the worldwide scale of the aquatic weed problem, Crop Prot. (7), 232-234 (1988)

Bais V.S. and Agrawal W.L., Seasonal Variation of Nutrient content in Hydrilla verticollata, J. Freshwater Biol, (3), 259265 (1993)

Brix H. and H.H. Schierup, The use of aquatic macrophytes in water pollution control, Ambio, (18), 100- 107 (1989)

Ghavzan N.J., Gunale V.R., Mahajan D.M. and Shirke D.R., Effects of environmental factors on ecology and distribution of aquatic macrophytes, Asian J. Plant Sci., (5), 871-880 (2006)

Swales S., Impacts of weed cutting on fisheries: an experimental study in a small lowland river, Fisheries Management, (13), 125-137 (1982)

Petre T., Aquatic weeds and fisheries production in developing regions of the world, J. Aquat. Plant Manage, (31), 5-10 (1993)
Scott W.A., Adamson J.K., Rollinson J. and Parr T.W. Monitoring of aquatic macrophytes for detection of longterm change in river systems, Environmental Monitoring and Assessment, (73), 131-153 (2002)

Uka U.N., Mohammed H.A. and S.I. Ovie, Current diversity of aquatic macrophytes in nigerian freshwater ecosystem. Braz, J. Aquat. Sci. Technol., (13), 9-15. (2009)

Garner P., Bass J.A.A. and Collet G.D., The effects of weed cutting on upon the biota of a large regulated river, Aquatic Conservation: Marine and Freshwater Ecosystems 6, 21-29 (1996)

Srivastava J.A. Gupta and H. Chandra, Managing water quality with aquatic macrophytes, Rev. Environ. Sci. Biotechnol., (7), 255-266 (2008)

Oki Y. and Une K., Relationship between occurrence of aquatic weeds and water quality in the natural water body (3), Weed Res. Jan., (34), 97-98 (1989)

Petre T., Fish, fisheries aquatic macrophytes and water quality in inland waters, Water Qual. Bull., (12), 103-106 (1990)

Akbay K.S., Using optimization and simulation techeniquesnto estimate initial weevil population, Journal of aquatic plants management (29), 21-24 (1991).

\begin{tabular}{|l|l|l|l|}
\hline \multirow{2}{*}{$\begin{array}{l}\text { No. } \\
\text { Nome of aq. Flora }\end{array}$} & \multicolumn{2}{|l|}{$\begin{array}{l}\text { Total \% of aquatic flora in } \\
\text { Shivni dam \& Chorkhund } \\
\text { dam }\end{array}$} \\
\hline 1 & Hydrillla & $25 \%$ & $30 \%$ \\
\hline 2 & Pond weed & $5 \%$ & $6 \%$ \\
\hline 3 & W. smart weed & $6 \%$ & $7 \%$ \\
\hline 4 & Cotton mat t. alga & $3 \%$ & $5 \%$ \\
\hline 5 & Common cattail & $4 \%$ & $6 \%$ \\
\hline 6 & Blue green alga & $9 \%$ & $10 \%$ \\
\hline 7 & Slimy green alga & $7 \%$ & $9 \%$ \\
\hline 8 & Curly-leaf P. weed & $2 \%$ & $3 \%$ \\
\hline
\end{tabular}




\begin{tabular}{|l|l|l|l|}
\hline 9 & Kalmi & $2 \%$ & $4 \%$ \\
\hline 10 & Eel weed & $3 \%$ & $6 \%$ \\
\hline 11 & Naiad & $3 \%$ & $4 \%$ \\
\hline
\end{tabular}

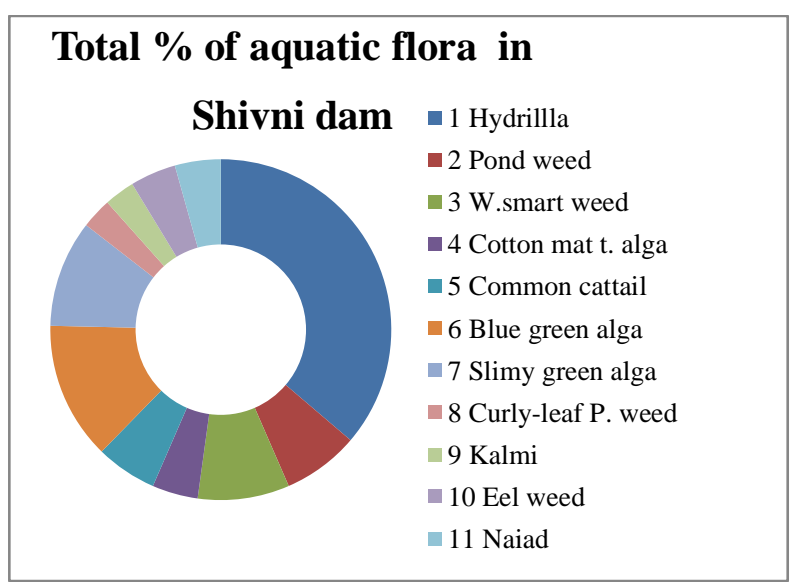

Total \% of aquatic flora in

Chorkhund dam

- 1 Hydrillla

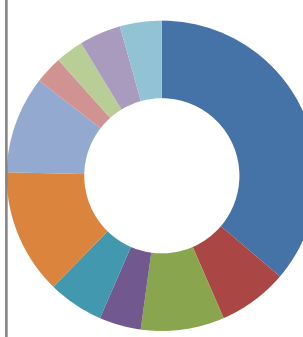

- 2 Pond weed

- 3 W.smart weed

- 4 Cotton mat t. alga

5 Common cattail

$\square$ Blue green alga

$\square$ Slimy green alga

$\checkmark 8$ Curly-leaf P. weed

9 Kalmi

$\square 10$ Eel weed

11 Naiad 